\title{
GERMINATION OF DOUM PALM (Hyphaene thebaica, L. MART.) SEEDS AS AFFECTED BY SOME SCARIFICATION TREATMENTS
}

\author{
S.M. Shahin ${ }^{1}$ and Azza M. S.Arafa ${ }^{2}$ \\ ${ }^{1}$ Botanical Gardens Res. Dept., Hort. Res. Inst., ARC, Giza, Egypt. \\ ${ }^{2}$ Ornamental Horticulture Dept., Faculty of Agric., Cairo Univ.,Egypt
}

\begin{abstract}
A field experiment was carried out during the seasons of 2005 and 2006 at Orman Botanical Garden, Giza, Egypt to study the effect of some scarification treatments on germination parameters, endocarp constituents and the quality of doum (Hyphaene thebaica, L. Mart.) seedlings.

The results indicated that endocarp punching or removal treatments slightly improved characters of germination and seedlings quality, which were significant in some cases, specially for punching treatments, while clefting the bare endocarp reduced such parameters to the minimal values in most cases of both seasons. However, the previous three treatments didn't obviously affect thickness, strength and chemical constituents of the bony endocarp. On the other hand, soaking in concentrated $\mathrm{H}_{2} \mathrm{SO}_{4}$, specially for 6 hrs., significantly improved germination (\%), germination velocity, mean germination rate, germination rate index, vigour index and quality of the resulted seedlings; which assessed as first leaf length, root branchlets number/ seedling and aerial parts and roots fresh and dry weights. The least means for endocarp thickness, strength and chemical constituents were also referred to the acid scarification with concentrated $\mathrm{H}_{2} \mathrm{SO}_{4}$ treatments.

Hence, soaking the bare seeds of doum (Hyphaene thebaica, L. Mart.) in concentrated $\mathrm{H}_{2} \mathrm{SO}_{4}$ for 6 hrs. can be recommended as a simple, cheap and quick way for high germination percent and good quality of seedlings.

Key words: Germination, doum palm, Hyphaene thebaica, sulfuric acid $\left(\mathrm{H}_{2} \mathrm{SO}_{4}\right)$, mechanical scarification, endocarp.
\end{abstract}

\section{INTRODUCTION}

Hyphaene thebaica L. Mart. Doum or Doom palm, Egyptian Doum, Gingerbread palm or Gingerbread tree (Fam. Palmaceae). To $6 \mathrm{~m}$. or more; commonly forked one or more times, but sometimes simple; leaf blades stiff, nearly orbicular to $90 \mathrm{~cm}$ long, cut to middle or deeper into 20 or more segments; fruit mostly obliquely ovoid or oblong, to 8-9 cm long, usually 1-seeded, dryish fibrous, endocarp thin, endosperm homogeneous. Nile region of N. Africa, but also grown in the tropics and subtropics for the unusual (for palms) branching habit (Bailey, 1976). Moreover, Huxley et al. (1992) added that doum is suitable for outdoor cultivation in the humid and dry tropics, making attractive lawn specimens. Fruit mesocarp is orange, edible 
and tasting for gingerbread. The powder of exo-and mesocarp is used as a sugared warm beverage for refreshing and blood pressure decrement.

Hard - seeded Hyphaene species often present considerable difficulties to nursery owners because of their hard, impermeable seed coats (pericarps). Such seeds often require pretreatments to obtain rapid and uniform germinating. In this concern, Patel (1996) described a technique for germinating the ornamental palm Hyphaene indica; as the fruits harvested at maturity and allowed to rest in the open without disturbance; one month after harvest, the fruits are placed in polyethylene bags and kept immersed in water for 10 days; the treated fruits are sown either in plots or boxes (unless metal or asbestos sheets in placed at a depth of approx. $30 \mathrm{~cm}$ in the plot below the fruits, the emerging sapling should be transplanted immediately after the emergence of the first leaf otherwise the roots penetrate too deep into the substratum). Germination \% ranged between 40-50\%, but many seedlings did not reach maturity. On Hyphaene thebaica, Moussa et al. (1998) found that intact fresh seeds had much lower germination $(0.6-2.5 \%)$ than either seeds with their pericarp removed (78-82\% or bare nuts (pericarp and endocarp removed, 73-85\%). Water - soaked seeds had higher germination than unsoaked ones for both the fresh and 13 - month - old seeds, the sulfuric acid treatment resulted in $28.3 \%$ germination and was the only treatment which resulted in any germination of intact seeds.

On other palm species, Daquinta et al. (1996) reported that scarification with concentrated sulfuric acid for 30 minutes gave $90 \%$ germination after 30 days in seeds of Chamaedorea seifrizii accompany with improving the quality of the resulted seedlings. Broschat (1998) revealed that germination rate was significantly improved by removing the thick, hard endocarp from Butia capitata fruits, whereas time to $50 \%$ of final germination rate was not affected by such treatment. On Caryota urens, however Maciel (2002) noticed that acid scarification via sulfuric acid dipping for 6 and 12 minutes negatively affected the seedling emergence ( 2 and $0 \%$ ), while dipping in water for 3 and 7 days increased seedling emergence to 42 and $50 \%$, respectively.

Similar results were also gained by Shahin and El-Shakhs (2001) on Nelumbium nucifera, Barnett (2002) on Pinus palustris, Dreesen (2003) on Salix irrorata, S. bebbiana and S. arizonica, Olmez et al. (2004) on Capparis ovata and Singh et al. (2005) who indicated that seed coat removal enhanced seed germination of Pongamia glabra, a medicinally important ornamental tree in India, up to $85 \%$. The seeds treated with concentrated $\mathrm{H}_{2} \mathrm{SO}_{4}$ and $\mathrm{HCl}$ for a minute showed $91.3 \%$ germination, while those treated with hot water $\left(50^{\circ} \mathrm{C}\right)$ exhibited highest germination $(98 \%)$.

This study, aims to detect the most suitable treatment for increasing and accelerating germination of the hard-coated seeds of doum palm.

\section{MATERIALS AND METHODS}

A field experiment was performed during 2005 and 2006 seasons at the Experimental Area of Orman Botanical Garden, Giza, Egypt to study the effect of some scarification treatments on germination parameters, endocarp constituents and quality of the produced seedlings of doum palm (Hyphaene thebaica, L. Mart.). 
The mature fruits were rasped by a greater to pull out the dry-fibrous pericarp. The bare seeds with bony endocarp (it diameter ranged between 3.5 and $4.2 \mathrm{~cm}$ ) were then subjected to the following treatments:

1- Control; as the bare endocarp received no treatment.

2- The bare endocarp was bored with a drill at three different positions.

3- The bare endocarp was clefted with a handsaw at the placental end and the facing distal one.

4- The bare endocapr was completely removed to get the bony endosperm alone (its diameter ranged between $2.5-3.4 \mathrm{~cm}$ ).

5-The seeds with bare endocarp were completely soaked in concentrated sulfuric acid $(98.5 \%$ for either 6 or 12 hours.

Treated seeds of various treatments were planted on April, $7^{\text {th }}$ in beds $100 \times 80$ $\mathrm{cm}$ filled with sand to the depth of $100 \mathrm{~cm}$, as every bed contained 20 seeds planted at $20 \times 20 \mathrm{~cm}$ for both seasons. The seeds were inserted in the sand until they were disappeared, and then covered with a thin layer of fine loam and compressed with a flate wooden piece to ensure the completely intact between the seeds and the soil. Thereafter, the beds were irrigated once every week to fill up and received the usual agricultural practices, specially digging up whenever needed.

The layout of the experiment during the two seasons was a completely randomized design (Das and Giri, 1986) with 3 replicates, as each bed containing 20 seeds expressed one replicate. Clearly visible plumule protrusion was used as a criterion for germination. So, the length of plumule $(\mathrm{cm})$ at germination was registered at first sight.

At the end of the experiment, on $10^{\text {th }}$ of September, the following data were recorded: germination percentage using the following equation: G. $\%=$ Total No. germinated seeds / Total No. raised seeds X 100, germination velocity (G.V.) as the mean No. days from sowing till germination become constant in the treatment, mean germination rate (MGR) as the mean No. days to attain $50 \%$ of the total germination (Odetoba, 1987), germination rate index (GRI) according to Bartled equation described by Hartmann and Kester (1983) and vigour index (VI) as indicated by Selvaraju and Selvaraj (1994) in the following equation: VI $=$ G. \% X mean length of plumule $(\mathrm{cm})$. Moreover, the first leaf length $(\mathrm{cm})$, leaf No./ seedling, root length $(\mathrm{cm})$, root branchlets No. / seedling and aerial parts and roots fresh and dry weights $(\mathrm{g})$ were also measured.

Immediately after treatment the bare seeds, the following determinations and analysis were conducted on the hard endocarp in the second season only:

- Endocarp thickness ( $\mathrm{mm})$ was measured at many positions using a steel caliper.

- Endocarp breaking strength (Kg. force) was monitored using an universal testing machine, Tinuis Olsen Testing Machine Co., Willow Grove, PA., USA at Mechanical Testing Lab., Fac. Engine., Cairo Univ., as the seeds were supported by fulcrum and force was applied to the midpoint of the seed (American Welding Society, 1988). 
- The percentages of ash, cellulose, hemicelluloses, lignin and extractives \%, as the usual main constituents of the hard endocarp were also determined according to McDonald and Kowng (2005).

The data were subjected to analysis of variance and the method of LSD was used to compare between means of treatments (Mead et al., 1993).

\section{RESULTS AND DISCUSSION}

\section{A- Effect of pre-germination treatments on germination characters :}

Results in Table 1 show that germination (\%) of doum seeds significantly increased when mechanically perforated with a drill or chemically scarified with concentrated $\mathrm{H}_{2} \mathrm{SO}_{4}$ for 6 and $12 \mathrm{hrs}$. in the two seasons, while clefting the bare endocarp with a handsaw reduced such parameter to the minimal values with non significant differences when compared to the control in both seasons. This may be due to arrival of the handsaw to the embryo and causing harm to it during cracking the placental end where the embryo is found. The least No. days for GV and MGR was recorded by soaking in concentrated $\mathrm{H}_{2} \mathrm{SO}_{4}$ for $6 \mathrm{hrs}$. in the two seasons, whereas prolonging the duration of soaking to $12 \mathrm{hrs}$. did not cause additional improvement in these traits. This result coincides with that obtained by Khan (1997) who found that increasing the period of scarification with sulfuric acid progressively increased the germination \% of Indian ricegrass seeds, but beyond a certain time, scarification adversely affects germination, presumably as a result of acid injury to the embryo. However, the MGR for control and endocarp clefting or removal was not calculated in both seasons because G. \% then did not reach $50 \%$.

Similarly that trend of GRI, as it was significantly increased in response to acid scarification for 6 or $12 \mathrm{hrs}$. in the two seasons, However, endocarp punching treatment gave a mean in the same rank of acid scarification in the second season only. The longest plumule $(\mathrm{cm})$ of germinated seeds was found to refer to sooking in concentrated sulfuric acid for 6 hrs., which significantly raised such trait to 1.80 and $1.76 \mathrm{~cm}$ in the first and second seasons, respectively, whilst increment the period of soaking to $12 \mathrm{hrs}$., elevated this parameter with significant difference only in the first season. On the other hand, endocarp clefting treatment resulted the shortest plumule giving 1.00 and $0.93 \mathrm{~cm}$ with significant differences when compared to control averages in the first and second seasons, respectively.

Due to increasing of both germination \% and plumule length, the vigour index (VI), as a real guide for germination flush was increased to reach the utmost high and significant means when bare seeds were soaked in concentrated $\mathrm{H}_{2} \mathrm{SO}_{4}$ for $6 \mathrm{hrs}$, which followed by soaking for $12 \mathrm{hrs}$. and then perforation of the bare endocarp treatment, as such treatments gave in general the greater VI values, which were 157.50, 148.75 and 123.75 in the first season and 176.00, 137.70 and 118.50 in the second one, respectively.

It seems, from the previous results that soaking in concentrated sulfuric acid for $6 \mathrm{hrs}$., treatment gave the best germination traits at all because its ability on reducing the thickness and strength of the sclera-endocarp to a level that permits the 
ease permeable of water and gasses across this weakened endocarp without injury the embryo, and that finally resulted in swelling and expand of endosperm, and cotyledons with emergence of embryo. Suda et al. (2003) added that Euphorbia heterophylla endosperm surrounds the embryo and its cotyledons increases in area after one day from the start of imbibitions.

The activities of endo- beta- mannanase and beta- mannasidase were higher over the pre-emergence compared to the post-emergence period and they may be involved in the process of germination. The activity of hydrolyses over the postemergence period may be related to the facilitation of cotyledon expansion by lowering endosperm resistance.

These results are in agreement with those recorded by Moussa et al. (1998) on Hyphaene thebaica, Broschat (1998) on Butia capitata, Shahin and El- Shakhs (2001) on Nelumbium nucifera, Dreesen (2003) on 3 species of Salix and Singh et al (2005) on Pongamia glabra.

Table 1. Effect of per-germination treatments on germination parameters of Hyphaene thebaica L. Mart. seeds during 2005 and 2006 seasons.

\begin{tabular}{|c|c|c|c|c|c|c|}
\hline $\begin{array}{l}\text { Pre-germination } \\
\text { treatments }\end{array}$ & $\begin{array}{l}\text { G } \\
\%\end{array}$ & $\begin{array}{l}\text { G.V. } \\
\text { (day) }\end{array}$ & $\begin{array}{l}\text { M.G.R } \\
\text { (day) }\end{array}$ & G.R.I. & $\begin{array}{l}\text { Plumule } \\
\text { length } \\
\text { (cm) }\end{array}$ & V.I. \\
\hline \multicolumn{7}{|c|}{2005} \\
\hline Control & 37.50 & 124.00 & - & 0.33 & 1.40 & 52.50 \\
\hline punching & 75.00 & 89.17 & 88.00 & 0.33 & 1.65 & 123.75 \\
\hline Endocarp clefting & 12.50 & 118.00 & - & 0.12 & 1.00 & 12.50 \\
\hline removal & 25.00 & 87.50 & - & 0.46 & 1.50 & 37.50 \\
\hline \multicolumn{7}{|l|}{ Soaking in concentrated } \\
\hline $\mathrm{H}_{2} \mathrm{So}_{4}$ for $6 \mathrm{hrs}$ & 87.50 & 86.29 & 79.75 & 0.58 & 1.80 & 157.50 \\
\hline $\mathrm{H}_{2} \mathrm{So}_{4}$ for $12 \mathrm{hrs}$. & 87.50 & 94.50 & 83.75 & 0.56 & 1.70 & 148.75 \\
\hline I.S.D. at 0.05 & 30.00 & 33.76 & 5.28 & 0.21 & 0.30 & 36.30 \\
\hline \multicolumn{7}{|c|}{2006} \\
\hline Control & 33.33 & 126.33 & - & 0.27 & 1.43 & 47.66 \\
\hline punching & 75.00 & 88.43 & 87.27 & 0.56 & 1.58 & 118.50 \\
\hline Endocarp clefting & 12.50 & 121.00 & - & 0.13 & 0.93 & 11.63 \\
\hline removal & 37.50 & 87.10 & - & 0.44 & 1.55 & 58.13 \\
\hline \multicolumn{7}{|l|}{ Soaking in concentrated } \\
\hline $\mathrm{H}_{2} \mathrm{So}_{4}$ for $6 \mathrm{hrs}$ & 100.00 & 85.00 & 78.56 & 0.58 & 1.76 & 176.00 \\
\hline $\mathrm{H}_{2} \mathrm{So}_{4}$ for $12 \mathrm{hrs}$. & 85.00 & 96.26 & 85.31 & 0.58 & 1.62 & 137.70 \\
\hline L.S.D. at $0.05 \%$ & 28.67 & 35.50 & 3.46 & 0.23 & 0.26 & 73 \\
\hline
\end{tabular}

G\%: Germination percentage, G.V.: Germination velocity, M.G.R.: Mean germination rate, G.R.I. Germination rate index and V.I.: Vigour index.

\section{B. Effect of pre-germination treatments on seedling growth:}

Data of seedling growth given in Table 2, as an aspect of development linked to G.V. and VI, indicated that most of treatments improved vegetative and root growth characters with various significant differences except for endocarp clefting treatment, 
which declined growth traits in most cases of the two seasons. However, the superiority was for soaking in concentrated sulfuric acid for $6 \mathrm{hrs}$., treatment, which gave the highest records comparing with control and all other treatments in both seasons.

Such results may indicate the role of concentrated $\mathrm{H}_{2} \mathrm{SO}_{4}$ in increasing $\mathrm{GV}$ and VI, which led to early germination, and consequently giving the growing embryo the time enough for more growth and high quality. Such gains, however are in parallel with those results of Daquinta et al. (1996) on Chamaedorea seifrizii, Shahin and El-Shakhs (2001) on nelumbo seeds and Olmez et al. (2004) who mentioned that the optimum chemical treatment for seed germination and high quality of seedlings in Capparis ovata was obtained by soaking the seeds in $0.2 \% \mathrm{KNO}_{3}$ for $8 \mathrm{hrs}$. after treatment with concentrated $\mathrm{H}_{2} \mathrm{SO}_{4}$ for 20 minutes.

Table 2: Effect of pergermination treatments on growth parameters of Hyphaene thebaica L. Mart. seedlings during 2005 and 2006 seasons.

\begin{tabular}{|c|c|c|c|c|c|c|c|c|}
\hline $\begin{array}{l}\text { Pre-germination } \\
\text { treatments }\end{array}$ & $\begin{array}{c}1^{\text {st }} \text { leaf } \\
\text { length } \\
(\mathrm{cm})\end{array}$ & $\begin{array}{c}\text { Leaves } \\
\text { No. } \\
\text { per } \\
\text { seedlin } \\
\text { (g) } \\
\end{array}$ & $\frac{\text { Root }}{\begin{array}{r}\text { Length } \\
\text { (cm) }\end{array}}$ & $\begin{array}{c}\text { Root } \\
\text { branchlets } \\
\text { No. } \\
\text { per } \\
\text { seedling }\end{array}$ & $\begin{array}{c}\text { Aerial } \\
\text { parts } \\
\text { F.W. } \\
\text { (g) }\end{array}$ & $\begin{array}{c}\text { Aerial } \\
\text { parts } \\
\text { D.W. } \\
\text { (g) }\end{array}$ & $\begin{array}{l}\text { Roots } \\
\text { F.W. } \\
\text { (g) }\end{array}$ & $\begin{array}{c}\text { Roots } \\
\text { D.W. } \\
\text { (g) }\end{array}$ \\
\hline \multicolumn{9}{|c|}{2005} \\
\hline Control & 61.80 & 2.00 & 63.42 & 34.00 & 14.78 & 3.95 & 14.72 & 5.10 \\
\hline punching & 60.75 & 2.33 & 70.33 & 42.50 & 16.43 & 4.46 & 16.31 & 5.86 \\
\hline Endocarp clefting & 52.00 & 1.00 & 65.00 & 35.00 & 10.90 & 2.78 & 14.20 & 5.39 \\
\hline removal & 70.50 & 2.50 & 67.36 & 38.33 & 15.36 & 3.16 & 15.10 & 5.50 \\
\hline \multicolumn{9}{|c|}{ Soaking in concentrated } \\
\hline $\mathrm{H}_{2} \mathrm{So}_{4}$ for $6 \mathrm{hrs}$ & 79.50 & 3.00 & 85.50 & 49.00 & 19.20 & 5.27 & 19.36 & 6.38 \\
\hline $\mathrm{H}_{2} \mathrm{So}_{4}$ for $12 \mathrm{hrs}$. & 72.60 & 2.33 & 78.76 & 45.28 & 17.42 & 4.65 & 17.83 & 5.87 \\
\hline L.S.D. at $0.05 \%$ & 10.50 & 0.88 & 7.33 & 5.76 & 1.56 & 1.23 & 1.50 & 0.81 \\
\hline \multicolumn{9}{|c|}{2006} \\
\hline Control & 58.70 & 2.00 & 60.33 & 31.00 & 13.56 & 3.56 & 13.90 & 4.78 \\
\hline punching & 70.50 & 2.33 & 73.50 & 43.80 & 16.50 & 4.45 & 16.50 & 5.93 \\
\hline Endocarp clefting & 56.33 & 1.00 & 58.81 & 31.37 & 9.79 & 2.76 & 12.78 & 4.82 \\
\hline removal & 62.50 & 2.40 & 62.30 & 35.18 & 12.58 & 2.63 & 13.86 & 5.00 \\
\hline \multicolumn{9}{|c|}{ Soaking in concentratec } \\
\hline $\mathrm{H}_{2} \mathrm{So}_{4}$ for $6 \mathrm{hrs}$ & 72.86 & 3.00 & 79.66 & 46.50 & 17.70 & 4.89 & 17.35 & 5.63 \\
\hline $\mathrm{H}_{2} \mathrm{So}_{4}$ for $12 \mathrm{hrs}$. & 72.50 & 2.50 & 74.10 & 45.00 & 16.18 & 4.33 & 16.10 & 5.21 \\
\hline L.S.D. at 0.05 & 9.86 & 0.76 & 9.26 & 5.50 & 2.13 & 0.98 & 2.17 & 0.85 \\
\hline
\end{tabular}

F.W.: Fresh weight and D.W.: Dry weight

\section{Effect of pre-germination treatments on endocarp characteristics:}

Strength, in general can be defined as the ability of a material to withstand an applied load (Wulpi, 1986). Such strength, however linearly decreased with the decrement in seed coat thickness (Khan, 1997). 
In the current work, data in Table (3) show that punching or clefting operations had no effect on endocarp thickness, although they were decreased its breaking strength by about 15.33 and $31.72 \%$, respectively.

On the other hand, soaking in concentrated $\mathrm{H}_{2} \mathrm{SO}_{4}$ for either 6 or $12 \mathrm{hrs}$., greatly reduced the thickness of endocarp by about 32.50 and $41.75 \%$, and consequently the strength by about 46.63 and $64.80 \%$, respectively. That of course could help the embryo to go out through the weakened endocarp without resistance. Owing to removing of the endocarp, data of thickness, strength and chemical constituents for endocarp removal treatment were not recorded.

Concerning the chemical compositions of the hard endocarp, data in Table 3 reveal that ash, cellulose, hemicelluloses, lignin and extractives percentages were not affected by either endocarp punching or clefting treatments, whereas soaking in concentrated sulfuric acid for 6 or 12 hrs., markedly decreased such constituents with the exception of extractives, which clearly increased. Such gains, however indicate the role of concentrated $\mathrm{H}_{2} \mathrm{SO}_{4}$ in softening and enfeeblement the concrete(solid) endocarp of doum seeds through reducing thickness and strength coupled with dissolving the complicated compounds consisting the endocarp such as cellulose, hemicelluloses and lignin to simple and soluble extractives, and that will finally lead to raising and accelerating germination process. On the same line were those findings mentioned by Shahin and El- Shakhs (2001) on Nelumbium nucifera, Dreesen (2003) on 3 species of Salix and Singh et al. (2005) on Pongamia glabra.

From the foretasted results, it could be recommended to soaking doum (Hyphaene thebaica, L. Mark) bare seeds in concentrated $\mathrm{H}_{2} \mathrm{SO}_{4}$ for $6 \mathrm{hrs}$., to get the highest and fastest germination associated with good quality of seedlings.

Table 3: Effect of per-germination treatments on endocarp characteristics of Hyphaene thebaica L. Mart. seeds during 2006 season.

\begin{tabular}{|c|c|c|c|c|c|c|c|}
\hline \multirow{2}{*}{$\begin{array}{l}\text { Pre-germination } \\
\text { treatments }\end{array}$} & \multirow{2}{*}{$\begin{array}{c}\text { Endocarp } \\
\text { thickness } \\
(\mathrm{mm})\end{array}$} & \multirow{2}{*}{$\begin{array}{c}\text { Endocarp } \\
\text { breaking } \\
\text { strength } \\
\text { (Kg. Force) }\end{array}$} & \multicolumn{5}{|c|}{ Endocarp constituents (\%) } \\
\hline & & & Ash & Cellulose & Hemi. & Lignin & Extr. \\
\hline Control & 4.00 & 1647.5 & 4.33 & 66.31 & 13.29 & 12.85 & 3.22 \\
\hline Punching & 3.92 & 1395.0 & 3.96 & 66.26 & 13.20 & 12.80 & 3.78 \\
\hline Endocarp clefting & 3.98 & 1125.0 & 3.98 & 66.09 & 13.17 & 13.00 & 3.76 \\
\hline $\begin{array}{l}\text { removal } \\
\text { Soaking } \\
\text { in concentrated }\end{array}$ & - & - & - & - & - & - & - \\
\hline $\mathrm{H}_{2} \mathrm{So}_{4}$ for $6 \mathrm{hrs}$ & 2.70 & 879.2 & 2.76 & 44.28 & 8.86 & 6.89 & 37.21 \\
\hline $\mathrm{H}_{2} \mathrm{So}_{4}$ for $12 \mathrm{hrs}$. & 2.33 & 580.0 & 2.10 & 32.94 & 6.70 & 5.21 & 53.05 \\
\hline
\end{tabular}

Hemi. $=$ Hemicelluloses Extr. $=$ Extractives. 


\section{REFERENCES}

American Welding Society, A.W.S. (1988). Standard for A.W.S. Certification of Welding Inspectors. Certify Welding Inspector, A.W.S., Quality control (Q.C.), 88 (1): 35.

Bailey, L.H. (1976). Hortus Third, Macmillan Publishing Co., Inc., 866 Third Avenue, New York, N.Y. 10022, 1290.

Barnett, J.P. (2002). Activities that increase germination and establishment of longleaf pine seedlings in containers. General Technical Report Southern Res. Station, USDA Forest Service, 56: 21- 23.

Broschat, T.K. (1998). Endocarp removal enhances Butia capitata, (Mark) Becc. (Pindo palm) seed germination. Hort. Technology, 8 (4): 586-587.

Daquinta, M.; O. Concepcion; I. Capote; I. Cobo; M. Escolona and C. Borroto (1996). In vitro germination of Chamaedorea seifririi. Principes, 40 (2):112113.

Das, M.N. and N.C. Giri (1986). Design and Analysis of Experiments, $2^{\text {nd }}$ Ed., Published by Mohinder Singl Sejwal for Wiley, New Delhi 110 002, 488.

Dreesen, D.R. (2003). Propagation protocol for container willows in the Southwestern US using needs. Native Plants J., 4 (2): 118- 124.

Hartmann, H.T. and D. E. Kester (1983). Plant Propagation, Principles and Practices. Prentice- Hall Inc., Englewood Cliffs, New Jersey, 662.

Huxley, A., M. Griffiths and M. levy (1992). The New Royal Hort. Soc. Dict. Gar., the Stockton Press, New York, 257 Park Avenue South, N.Y. 100 10, USA, 2,747 .

Khan, A.A. (1997). Quantification of seed dormancy: physiological and molecular considerations. Hort. Science, 32 (4): 609-614.

Maciel, N. (2002). Effects of fruit storage, seed soaking and scarification and gibberellic acid on Caryota urens emergence. Proceedings of Inter American Society for Tropical Hort., 46: 106-109.

McDonald, M. B. and F. Y. Kowng (2005): Flower seeds Biology and Technology. $1^{\text {st }}$ Ed., waling Ford, Uk, CABI publishing. 372.

Mead, R.; R.N. Curnow and A. M. Harted (1993). Statistical Methods in Agriculture and Experimental Biology, $2^{\text {nd }}$ Ed., Chapman \& Hall Ltd., London, 335.

Maussa, H.; H. Margolis; P. Dube and J.O. Dongo (1998). Factors affecting the germination of doum palm (Hyphaene thebaica, Mark) seeds from the semiarid zone of Niger, West Africa. Forest Ecology and Management, 104 (1/3): $27-41$.

Odetola, J. A. (1987).Studies on seed dormancy, viability and germination in ornamental palms. Principes, 31 (1): 24- 30.

Olmez; Z. Z. Yahyaoglu and A.O. Ucler (2004). Effects of $\mathrm{H}_{2} \mathrm{SO}_{4}, \mathrm{KNO}_{3}$ and $\mathrm{GA}_{3}$ treatments on germination of caper (Capparis ovata, Desf.) seeds. Pakistan J. Biological Sci., 716: 879-882. 
Patel, M.M. (1996). A note on an improved germination technique for Hyphaene indica, L. J. Appl. Hort., 2 (1/2): $148-152$.

Selvaraju, P. and J.A. Slevaraj (1994). Effect a pre-sowing treatments on germination and vigor of seed in marigold (Tagetes erecta, L.). Madras Agric. J., 81(9): 496 - 497.

Shahin, S.M. and M.H. El-Shakhs (2001). Nelumbo seed germination as affected by some pre-germination treatments. J. Agric. Res., Tanta Univ., 27 (1): 179 198.

Singh, K.P.; G. Dhakre and S.V.S. Chauhan (2005). Effect of mechanical and chemical treatments on seeds germination in Pongamia glabra L. Seed Research, 33 (2): $169-171$.

Suda, C.N.; M.S. Buckeridge and J.F. Giorgini (2003). Cell wall hydrolyses in the seeds of Euphorbia heterophylla, L. during germination and early seedling development, Brazilian J. Plant Physical., 15(3): 135-143.

Tappi (1988) .T 203, 204 and 222, or - 88.

Wulpi, D.J. (1985). Understanding How Components Fail - Amer. Soc. For Metals, Metals Park, Ohio, 44073, 51. 


\section{إنبلت بذور نخلل الدوم:ألثرة ببهض معاملات الخش}

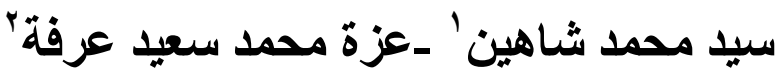

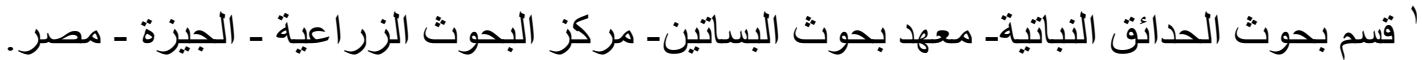

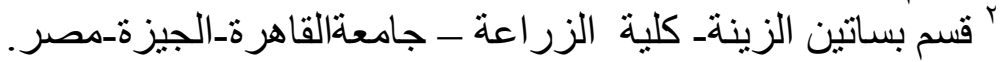

أجريت تجربـة حقلية بحديقة الأورمان النباتيـة، الجيزة، مصر وذلكاتك خلال الموسمين

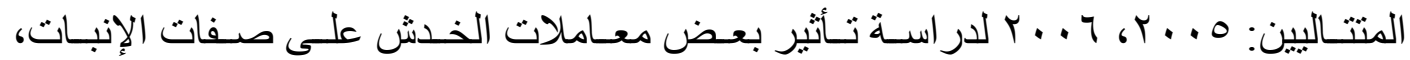
L. Mart.)

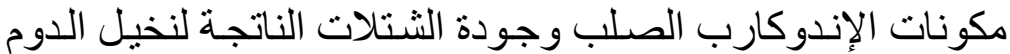
- (Hyphaene thebaica, ولقت أوضحت النتائج أن معاملتي ثقب الإندوكارب أو إز الته بالكامل أحدثتا تحسنأ طفيفاً

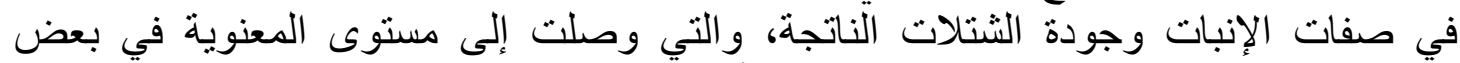

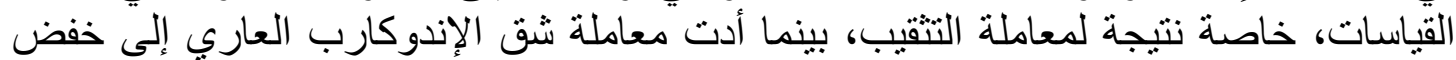

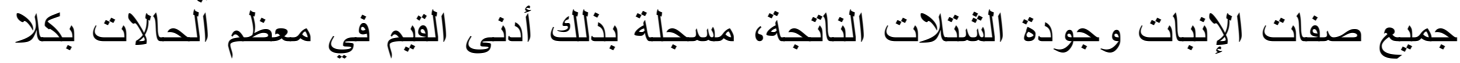

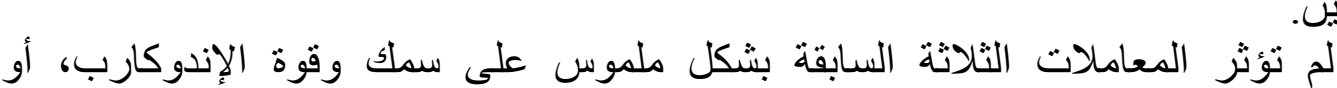

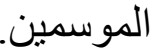

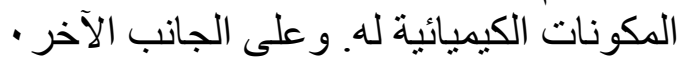

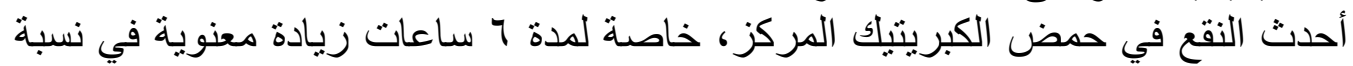

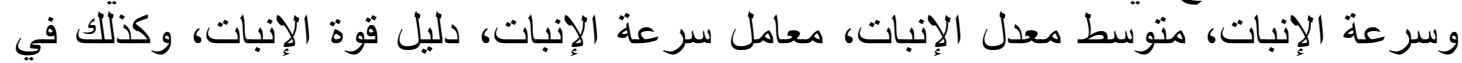

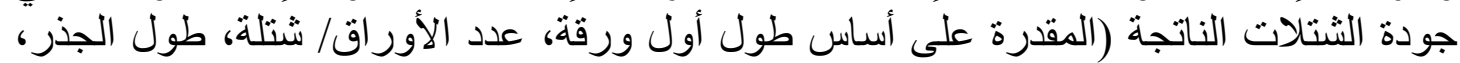

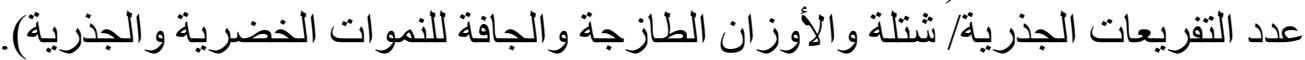

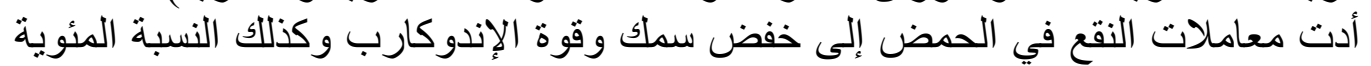

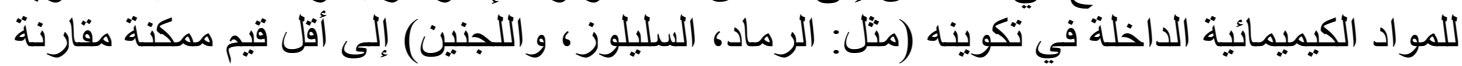

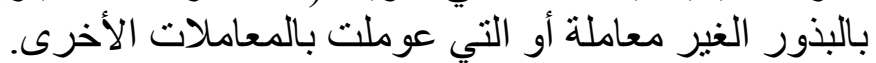

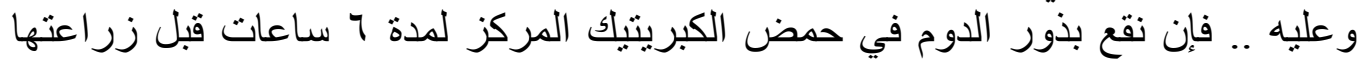

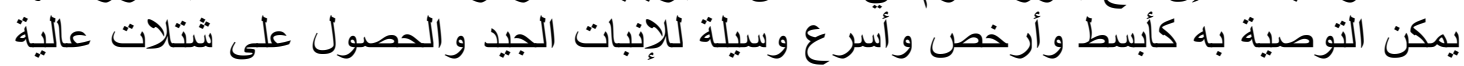

